\section{Acaricidal Coumarins from the Medicinal Plant Acokanthera schimperi}

\section{Abstract}

Two coumarins were isolated from the plant Acokanthera schimperi (Apocynaceae), and the in vitro larvicidal activities of these compounds against East Coast Fever vector Rhipicephalus appendiculatus was investigated. The mortalities of the larvae were determined after $48 \mathrm{~h}$ post treatment. The finding demonstrated that Compound $\mathbf{1}$ and $\mathbf{2}$ as amixture registered $\mathrm{LC}_{50} / \mathrm{LC}_{90}$ values of 2.96/6.09 mg/ $\mathrm{ml}$. These findings could be useful as lead compounds for the development of acaricides. Additionally, these findings underscore the fact that this plant is used ethnomedicinally as an acaricide. The discovery of plant compounds that may control ticks could be of great value to the agricultural sector.

Keywords: Coumarin; Acokanthera schimperi; Acaricidal; Rhipicephalus appendiculatus; Larvicidal

Received: November 26, 2015; Accepted: December 02, 2015; Published: December 08,2015

\section{Introduction}

Worldwide, the economic losses caused by ticks and tick borne diseases (TBDs) in cattle are estimated at US\$13.9-18.7 billion annually. The annual cost for importing acaricides have been estimated at US\$16 million in Kenya, \$26 million in Tanzania, and $\$ 26$ million in Uganda [1]. Tick borne diseases (TBDs) constitute a major constraint to livestock production in developing countries within tropical areas especially in the smallholder sector of East, Central and Southern Africa [1]. Tick infestations are controlled with chemical acaricides, is increasingly becoming unsustainable, due to the high incidence of acaricide resistance within tick populations and food safety concerns relating to toxic residues in milk and meat $[2,3]$. Synthetic chemical repellents are also commonly accepted means of personal protection against tick bites. These ticks are active host seekers that are strongly attracted to host producing carbon dioxide $\left(\mathrm{CO}_{2}\right)$ [4]. Development of resistance to commercial acaricides by ticks has stimulated the search for alternative control strategies. Plant extracts provide a potential alternative to existing acaricides, based on promising results with other plant species. A. schimperi and Psiadia punctulata have been reported to have potential acaricidal activity [5]. The medicinal plants that are widely used by the locals in Samburu district or used as a remedy for specific ailment are Carissa spinarum, Clausenaanisata and Acokanthera schimperi $[6,7]$. A. schimperi occurs at the margins of dry forest, in relict forest, thickets, grass lands and bush

\section{Jared O Owino ${ }^{1}$, Josphat C Matasyoh ${ }^{1}$ and Abdi Y Guliye ${ }^{2}$}

\section{Department of Chemistry, Egerton University, PO Box 536, Egerton-20107, Kenya \\ 2 Department of Animal Sciences, Egerton University, PO Box 536, Egerton-20107, Kenya}

\section{Corresponding author: Jared O Owino}

\section{” owinojared790@gmail.com}

Department of Chemistry, Egerton University, PO Box 536, Egerton-20107, Kenya.

Tel: +254735776144

Citation: Owino BO, Matasyoh JC, Guliye AY. Acaricidal Coumarins from the Medicinal Plant Acokanthera schimperi. J Org Inorg Chem. 2015, 1:1.

lands, at $1100-2400 \mathrm{~m}$ altitude and with $600-1000 \mathrm{~mm}$ [8]. The poison is a cardenolide, closely resembling ouabain, one of the active components in a traditional African arrow poison, long celebrated for its power to kill elephants [9]. The medicinal plants that are widely used by the locals or used as a remedy for specific ailment are Carissa spinarum, Clausenaanisata and A. schimperi [6]. The genus Rhipicephalus comprises 70 species. These small to medium-sized ticks with short, broad palps are usually inornate and have eyes and festoons. They are usually three-host ticks, although some have a two-host cycle (e.g., $R$. evertsi) [10]. R. appendiculatus, the brown ear tick, is the most important Rhipicephalid tick in East and Southern Africa where it occurs on a wide variety of domestic and wild ruminants. This tick prefers to feed on the ears of its hosts in the adult stage of its three-host life cycle [1]. The rapidly rising costs of tick control make it increasingly important to consider the economics of strategies for the control of ticks and tick-borne diseases [11]. Tick control by use of chemical acaricides is also fraught with various problems like residues, environmental pollution, and high cost, clearly demanding the need for alternative approaches. 
Even though many plants extracts with promising acaricidal effects have been reported in literature, the feasibility of many of these extracts for the control of ticks infesting animals, has not been adequately studied [12]. Natural products from botanical sources used in traditional medicine may combat multiple drug resistant infectious diseases through elucidation and validation of biological compounds with novel mechanisms of action [13]. This knowledge is however dwindling rapidly, due to changes towards a western lifestyle, overgrazing and over exploitation of plant resources has rapidly lead to the decline of plant material available [14]. Ethno pharmacology and natural products drugs still remains a significant hope in improving the livelihoods of the rural communities. Many modern pharmaceuticals have their origin in the ethno medicine and ethno veterinary medicine, which relies upon the local pharmacopoeia [15]. We therefore, describe here the isolation, structure elucidation and acaricidal activity of a mixture of two coumarins compounds; 8-hydroxy-2H -chromen -2- one 1 and $(E)$-methyl-4- hydroxyl -7- oxo-5- (2-oxo$2 \mathrm{H}$-Chromen -8-yloxy) oct-2- enoate 2 from $A$. schimperi. The two coumarins are for the first time being reported as isolated from $A$. schimperi and to have acaricidal activity against $R$. appendiculatus.

\section{Materials and Methods}

\section{Collection of plant material}

Plant material of $A$. schimperi were collected from Bomet county, Kapkimolwa, Longisa $\left(00^{\circ} 52^{\prime} \mathrm{S}\right.$ and $\left.035^{\circ} 25^{\prime} \mathrm{E}\right)$ and were identified by a taxonomist at the department of biological sciences of Egerton University, where a voucher specimen was deposited. The materials were then taken to the center for Herbal research in Egerton University where they were dried under shade to a constant weight. The material was then ground to a fine powder using Wiley mill model 4.

Table 1 NMR data for compounds 1 and 2 (DMSO).

\begin{tabular}{|c|c|c|c|c|}
\hline \multirow{2}{*}{ Carbon Position } & \multirow{2}{*}{$\begin{array}{l}\text { Compound } 1 \\
\qquad \delta_{H(J \text { in } \mathrm{Hz})}\end{array}$} & \multicolumn{3}{|c|}{ Compound 2} \\
\hline & & $\delta_{c}$ & $\delta_{\mathrm{H}(\mathrm{Jin} \mathrm{Hz})}$ & $\delta_{c}$ \\
\hline 2 & - & 161.8 & - & $165 . .9$ \\
\hline 3 & $6.20, d(9.52)$ & 111.8 & $6.13, \mathrm{~d}(15.93)$ & 114.3 \\
\hline 4 & $7.93, d(9.52)$ & 144.9 & $7.38, d(15.67)$ & 145.6 \\
\hline $4 a$ & - & 111.9 & - & 115.8 \\
\hline 5 & $6.79, \mathrm{dd}(2.18,8.52)$ & 113.6 & $6.96, \mathrm{dd}(2.06,8.22)$ & 121.9 \\
\hline 6 & $7.52, \mathrm{~d}(8.52)$ & 130.2 & $6.76, d(8.22)$ & 116.3 \\
\hline 7 & $6.72, d(1.78)$ & 102.6 & $7.03, d(2.06)$ & 114.9 \\
\hline 8 & - & 160.9 & - & 146.9 \\
\hline $8 a$ & - & 155.9 & - & 148.9 \\
\hline $1^{\prime}$ & - & - & $5.01, q$ & 71.5 \\
\hline $2^{\prime}$ & - & - & $3.17, \mathrm{brd}$ & 73.5 \\
\hline $3^{\prime}$ & - & - & $5.77, \mathrm{t}$ & 125.8 \\
\hline $4^{\prime}$ & - & - & $5.39, d$ & 132.0 \\
\hline $5^{\prime}$ & - & - & - & 174.1 \\
\hline $6^{\prime}$ & - & - & $3.56, \mathrm{~s}$ & 52.3 \\
\hline $7^{\prime}$ & - & - & $1.76, \mathrm{~d}$ & 37.6 \\
\hline $8^{\prime}$ & - & - & - & 207.5 \\
\hline $9^{\prime}$ & - & - & $2.08, \mathrm{~s}$ & 31.1 \\
\hline
\end{tabular}

\section{Extraction and isolation}

The air dried powder of $A$. schimperi leaves was soaked in methanol, exhaustively extracted at room temperature and concetrated in vacou at $40^{\circ} \mathrm{C}$. The methanol crude extract obtained was suspended in water and subjected to sequential partioning with hexane and ethyl acetate. The ethylacetate fraction was then chromatographed over silica gel column, eluent 6:4 ethyl acetate -methanol solvent mixtures, yielding two fractions which were further subjeted to silica gel preparative thin layer chromatography (PTLC) using 4: 6 ethyl acetate -methanol mixture as an eluent. Further purification using reversed phase high perfomance liquid chromatography (HPLC) with gradient elution with water and acetonitrile resulted into compounds 1 and 2. The NMR spectra were recorded on the Bruker Advanced $500 \mathrm{MHz}$ NMR spectrometer. All the readings were done in dimethyl sulfoxide (DMSO) and chemical shifts assigned by comparing with the residue proton and carbon resonance of the solvent. Tetramethyl silane (TMS) was used as the internal standard and the chemical shifts were given as $\delta(\mathrm{ppm})$. The mass spectra of the compounds were recorded on Finnigan Triple Quadrupol spectrometer (TSQ-70) with high-resolution electron spray ionization (ESI) method. The Thermo XcaliburQual computer software was used in the analysis of the mass chromatograms (Table 1). Spectral data of compound 1; HREIMS: $\mathrm{m} / \mathrm{z} 163.04[\mathrm{M}+\mathrm{H}]^{+}$, calculated for $\left[\mathrm{C}_{9} \mathrm{H}_{6} \mathrm{O}_{3}+\mathrm{H}\right]^{+}(\mathrm{m} / \mathrm{z}$ 163.143. ${ }^{1} \mathrm{H}(\mathrm{DMSO}, 500 \mathrm{MHz}) \delta: 6.20(\mathrm{H}, \mathrm{d}, \mathrm{H}-3) 6.72(\mathrm{H}, \mathrm{d}, \mathrm{H}-7), 6.79(\mathrm{H}$, $\mathrm{d} \mathrm{d}, \mathrm{H}-5), 7.52(\mathrm{H}, \mathrm{d}, \mathrm{H}-6), 7.93(\mathrm{H}, \mathrm{d}, \mathrm{H}-4) .{ }^{13} \mathrm{C}-\mathrm{NMR}$ (DMSO, 500 $\mathrm{MHz}$ ) $\delta: 102.6(\mathrm{C}-7), 111.8(\mathrm{C}-3), 111.9(\mathrm{C}-4 \mathrm{a}), 113.6(\mathrm{C}-5), 130.2(\mathrm{C}-$ 6),144.9(C-4), 155.9(C-8a), 160.9(C-8), 161.8(C-2). Spectral data of compound 2; HREIMS: $\mathrm{m} / \mathrm{z} 367.04[\mathrm{M}+\mathrm{Na}-2 \mathrm{H}]^{-}$calculated for $\left[\mathrm{C}_{18} \mathrm{H}_{18} \mathrm{O}_{7}+\mathrm{Na}-2 \mathrm{H}\right]-367.329 .{ }^{1} \mathrm{H}$ (DMSO, $\left.500 \mathrm{MHz}\right) \delta: 1.76(2 \mathrm{H}$, d, $\left.H-7^{\prime}\right), 2.08\left(3 \mathrm{H}, \mathrm{s}, \mathrm{H}-9^{\prime}\right), 3.17\left(2 \mathrm{H}, \mathrm{brd}, \mathrm{H}-2^{\prime}\right), 3.56\left(3 \mathrm{H}, \mathrm{s}, \mathrm{H}-6^{\prime}\right)$, 5.01(H, q, H-1'), 5.77(H, t, H-3'), 6.13(H, d, H-3), 6.76(H, d, H-6), 6.96(H, d d, H-5), 7.03(H, d, H-7), 7.38(H, d, H-4). ${ }^{13} \mathrm{C}-\mathrm{NMR}$ (DMSO, $500 \mathrm{MHz}) \delta$ : 31.1(C-9'), 37.6(C-7'), 52.3(C-6'), 71.5(C-1'), 73.5(C- 
$\left.2^{\prime}\right), 114.3(\mathrm{C}-3), 114.9(\mathrm{C}-7), 115.8(\mathrm{C}-4 \mathrm{a}), 116.3(\mathrm{C}-6), 121.9(\mathrm{C}-5)$, 125.8(C-3'), 132.0(C-4'), 145.6(C-4), 146.9(C-8), 148.9(C-8a), 165.9(C-2), 174.1(C-5'), 207.5(C-8').

\section{Rearing of larvae}

The larvae that were used for bio assay were reared according to ref. [16]. A circumference of approximately $22 \mathrm{~cm}$ of hair from the back of the rabbit was first shaved. This allowed porcelain cloth that was folded cylindrically attached at the back of the rabbit at the shaved area using conta glue. Male and female $R$. appendiculatus were placed inside the folded porcelain cloth at the back of the rabbit. The rabbit was then placed at the cage and then fed with rabbit pellets and water. A collar like object was also placed at the neck of the rabbit to prevent it from rubbing the back, which was due to possible irritation from the tick bites. After the ticks had fed for about 6 days, adult male and female $R$. appendiculatus mate. Complete engorgement of the female tick then followed, as the tick fed on the rabbit for a period of 4 days. Once fully engorged the females dropped off the rabbit and were placed on the glass vials covered with net cloth. Within 2-5 days later, the engorged female laid eggs. The eggs were then incubated at $25-27^{\circ} \mathrm{C}$ and $80 \%$ relative humidity for $21-30$ days followed by hatching to larvae. The larvae are able to stay for a period of six months without having a meal and only moult to the next stage (nymph) once they are fed. The vials with larvae were wrapped in cotton net cloth for oxygen supply and transported to the University laboratory for bioassay within 24 hours to perform subsequent bio assay experiments.

\section{Acaricidal bioassay}

The bio-assays were performed at Egerton University biotechnology laboratory. Ten larvae in triplicate were used to test for the effect of the compounds isolated to observe the mortality of $R$. appendiculatus larvae examined under microscope. The compounds were solubilised in (DMSO) and diluted with distilled water to give $5.4 \mathrm{mg} / \mathrm{ml}$ of stock solution. A series of seven concentrations of the bio-active phytochemicals ranging from 2.0, 2.4, 3.0, 3.6, 4.2, 4.8 and $5.4 \mathrm{mg} / \mathrm{ml}$, were prepared by serial dilution, where DMSO was kept at an optimised concentration of $4 \%$ volume by volume $(\mathrm{v} / \mathrm{v})$, at which the concentration did not affect the acaricidal mortality. A series of concentrations of both the positive control $(0.2 \% \mathrm{v} / \mathrm{v}$ amitraz) and negative control (DMSO and distilled water), was also prepared. The insect bioassay was carried out by the dipping method where the larvae were sprayed with test sample. The filter paper was dipped in the test solution. Ten larvae were placed at the centre of a filter paper and then allowed to move around. Larvae were also placed on filter paper dipped in DMSO and distilled water. Mortality was observed after 48 hours. The larvae were examined under a microscope and those that did not respond to human breath $\left(\mathrm{CO}_{2}\right)$ and tactile stimulus for each test solution was considered dead, and was expressed as a percentage mortality of each concentration.

\section{Statistical analysis}

Probit analysis of concentration mortality data was conducted to estimate the $\mathrm{LC}_{50}$ and $\mathrm{LC}_{90}$ values using the statistical package for social sciences SPSS version 20 software.

\section{Results}

Compound 1 showed five aromatic proton resonances in the molecule and identified as with molecular ion peak $\mathrm{m} / \mathrm{z} 163.04$ $[\mathrm{M}+\mathrm{H}]^{+}$, calculated for $\left[\mathrm{C}_{9} \mathrm{H}_{6} \mathrm{O}_{3}+\mathrm{H}\right]^{+}(\mathrm{m} / \mathrm{z}$ 163.143), using high resolution positive electron impact mass spectrometry (HREIMS) at 1.82 minutes retention time. The compound was identified as 8-hydroxy-2 $\mathrm{H}$-chromen -2- one with a molecular formula $\mathrm{C}_{9} \mathrm{H}_{6} \mathrm{O}_{3}$. The doublet at $\delta 6.20\left(\mathrm{~J}_{3,4}=9.52 \mathrm{~Hz}\right)$ and $\delta 7.93\left(\mathrm{~J}_{4,3}=9.52 \mathrm{~Hz}\right)$ are characteristic of $\mathrm{H}-3$ and $\mathrm{H}-4$ Coumarin moety [17]. The rather up field chemical shift of the $\mathrm{H}-3$ was due to the possible shielding influence of the $\mathrm{C}=\mathrm{O}$ function, while the relatively down field chemical shift of the 4- $\mathrm{H}$ may be attributed to the de shielding effect of $\mathrm{C}=\mathrm{O}$ function operating at $\mathrm{C}-4$. The $\mathrm{H}-7$ aromatic proton appeared at $\delta 6.72$ as a doublet $\left(J_{5,7}=1.78 \mathrm{~Hz}\right)$. The value of coupling constant showed the presence of $\mathrm{H}-7$ Meta proton. A doublet of doublet at $\delta 6.79\left(\mathrm{~J}_{5,6}=8.52 \mathrm{~Hz}\right.$ and $\left.\mathrm{J}_{5,7}=2.18 \mathrm{~Hz}\right)$ was assigned to the $\mathrm{H}-5$ aromatic proton. The larger coupling constant ( $\mathrm{J}=8.52 \mathrm{~Hz}$ was due to the $\mathrm{H}-6$ ortho proton while the smaller coupling constant $\mathrm{J}=2.18 \mathrm{~Hz}$ was due to $\mathrm{H}-7$ Meta coupling $[18,19]$. This showed a substitution at $\mathrm{C}-8$. The $\mathrm{H}-5$ on the other hand showed COSY interaction with the H-6. The appearance of $\mathrm{H}-5$ as doublet of a doublet with one of the coupling constant $\mathrm{J}=2.18 \mathrm{~Hz}$ could only result if the $\mathrm{OH}$ was placed at $\mathrm{C}-8$. From literature, Coumarin compounds have most of their substituent groups at C-7 and C-8, whether glycoside moiety or hydroxyl group [20-25] and according to ref. [21] the substitution at C-7 leaves a proton at $\mathrm{C}-8$ to be a singlet, which was not the case with proton NMR that was obtained. A doublet at $\delta 7.52$ and J $=8.52 \mathrm{~Hz}$ signified the presence of proton at the ortho position. The ${ }^{13} \mathrm{C}-\mathrm{NMR}$ spectrum of the compound $\mathbf{1}$ showed a nine carbon resonances in the molecule. The nine signals corresponding to basic coumarin skeleton are $(\delta 102.6,111.8,111.9,113.6,130.2$, $155.9,160.9$, and 161.8) [17,25-27]. The C-2 lactone carbon appeared at $\delta 161.8$. The $\mathrm{C}-3$ and $\mathrm{C}-4$ resonated at $\delta 111.8$ and $\delta$ 144.9 respectively. The down field chemical shift noted on the C-4 was due to the resonance of the lactone carbonyl. The C-5 appeared at $\delta 113.6$, while C-6 appeared at $\delta 130.2$. The C-7 appeared at $\delta 102.6$ and the C-8 appeared at $\delta 160.9$. The down field chemical shift of $\mathrm{C}-8$ showed the resonance of oxygen function on the carbon having the chemical shifts at $\delta 160.9$. The quaternary carbon signals 155.9 and 111.9 were assigned to the carbon $4 \mathrm{a}$ and $8 \mathrm{a}$ respectively. The ${ }^{1} \mathrm{H}-{ }^{13} \mathrm{C}$ connectivity's were established through HSQC spectrum. The H-4 $(\delta 7.93)$ showed cross peak with $\mathrm{C}-4(\delta$ 144.3) while $\mathrm{H}-3(\delta$ 6.20) in the HSQC spectrum showed cross peak with $\mathrm{C}-3(\delta 111.8)$. The $5-\mathrm{H}(\delta 6.79)$ showed a cross peak with the C-5 signal at $(\delta 113.6)$, while the H-6 $(\delta 7.52)$ showed a cross peak with C- 6 signal at $(\delta 130.2)$. The HMBC spectral data showed correlations between $\mathrm{H}-3(\delta 6.20)$ and the carbonyl at $(\delta 161.8)$. It also exhibited correlation with $\mathrm{C}-4 a(\delta$ 111.9). The doublet signal of $\mathrm{H}-4$ ( $\delta$ 7.93) showed correlation with C-2( $\delta 161.8), C-3(\delta 111.8), C-4 a(\delta 111.9)$, and $\mathrm{C}-8 \mathrm{a}(\delta$ 155.9). The doublet of doublet signal of $\mathrm{H}-5$ showed correlation with C-4a( $\delta 111.9), \mathrm{C}-6(\delta 130.2), \mathrm{C}-7(\delta 102.6), \mathrm{C}-8(\delta$ $160.9)$ and $C-8 a(\delta$ 155.9). The doublet signal of $\mathrm{H}-6$ showed correlation with C-4a $(\delta 111.9), C-5(\delta 113.6), C-7(\delta 102.6)$ and $\mathrm{C}-8(\delta$ 160.9). The doublet signal of $\mathrm{H}-7(\delta 6.72)$ also showed correlation with C-4a ( $\delta 111.9), C-8(\delta 160.9), C-5(\delta 113.6)$, and 
C-8a ( $\delta$ 155.9) $[18,19] .{ }^{1} \mathrm{H}-{ }^{1} \mathrm{H}$ Cosy spectrum connectivity showed correlation of proton with signal at $\delta 6.20(\mathrm{H}-3)$ and that of $\delta 7.93$ $(\mathrm{H}-4)$ and vice versa. Similarly, proton signal at $\delta 7.52(\mathrm{H}-6)$ showed correlation with proton at $\delta 6.79(\mathrm{H}-5)$. There was a Meta coupling between the proton with signal $\delta 6.79(\mathrm{H}-5)$ and a coupling constant $\mathrm{J}=2.18 \mathrm{~Hz}$ and $\delta 6.72(\mathrm{H}-7)$ with coupling constant $\mathrm{J}=1.78 \mathrm{~Hz}$. Comparing these data with that in the literature, led to the conclusion that compound identified as 8-hydroxy-2H -chromen -2- one $\mathbf{1}$ is with structure shown in Figure 1. Compound $\mathbf{2}$ showed eighteen proton resonances in the molecule; five aromatic proton resonances and thirteen proton resonances attached on the prenyl group. There was a proton broad spectrum at $\delta 3.56$, which is associated with a methoxy proton. Two broad signals at $\delta 5.39$ and $\delta 5.77$ were accounted to C-4' and C-3' associated to methine protons attached to vinylic carbons [21]. A quartet signal at $\delta 5.01$ was accounted to $C-1^{\prime}$, methine protons. And a doublet signal at $\delta 1.76$ was due to $C-7^{\prime}$ methylene protons. The doublet at $\delta 6.13\left(\mathrm{~J}_{34} 15.93 \mathrm{~Hz}\right)$ and $\delta$ $7.38\left(\mathrm{~J}_{4,3}=15.67 \mathrm{~Hz}\right)$ were assigned to $\mathrm{H}-3$ and $\mathrm{H}-4$ respectively. The rather up field chemical shift of the $\mathrm{H}-3$ was due to the possible shielding influence of the $\mathrm{C}=\mathrm{O}$ function and the relatively down field chemical shift of the $\mathrm{H}-4$ is attributed to the de shielding effect of the $\mathrm{C}=\mathrm{O}$ function, which is operating at $\mathrm{C}-4$. The $\mathrm{H}-5$ aromatic proton appeared at $\delta 6.76$ as a doublet $\left(\mathrm{J}_{6^{\prime} 5} 8.22\right.$ $\mathrm{Hz})$. The value of the coupling constant showed the presence of $\mathrm{H}-5$ ortho protons. This showed a possibility of a substituent at C-8. And according to ref. [21] when substituent group is at C-7 a proton attached at $\mathrm{C}-8$ remains to be a singlet. A doublet of a doublet at $\delta 6.96\left(J_{5,7}=2.06 \mathrm{~Hz}\right)$ and $\delta 6.76\left(J_{5,6=} 8.22 \mathrm{~Hz}\right)$ was assigned to the $\mathrm{H}-5$ aromatic proton. The larger coupling constant $\mathrm{J}=8.22 \mathrm{~Hz}$ was due to the $\mathrm{H}-6$ ortho proton and the smaller coupling constant $\mathrm{J}=2.06 \mathrm{~Hz}$ was due to $\mathrm{H}-7$ Meta proton [18]. The $\mathrm{H}-5$ on the other hand showed COSY interaction with $\mathrm{H}-6$. The Appearance of $\mathrm{H}-5$ as a double of a doublet with one of the coupling constant $\mathrm{J}=2.06 \mathrm{~Hz}$ could only result if there was a substituent group placed at C-8. A doublet at $\delta 6.76, J=8.22 \mathrm{~Hz}$ showed presence of proton at the ortho position. The ${ }^{13} \mathrm{C}-\mathrm{NMR}$ spectrum of compound $\mathbf{2}$ showed eighteen carbon resonances in the molecule; nine being typical for umbeliferone skeleton and the other nine signals were ascribed to a prenyl group. The DEPT experiments classified the carbon signals to eight methines, including five for umbeliferone moiety at $C-3(\delta 114.3), C-4(\delta$ $145.6), C-5(\delta 121.9), C-6(\delta 116.3)$ and $C-7(\delta 114.9)$ and the other three were $C-1^{\prime}(\delta 71.5), C-3^{\prime}(\delta 125.8)$ and $C-4^{\prime}(\delta 132.0)$. One signal for methylene was attributed to $C-7^{\prime}(\delta 37.6)$. The $C-2$ lactone carbon appeared at $\delta$ 165.9. The C-3 and C-4 showed resonance at $\delta 114.3$ and $\delta 145.6$ respectively. The down field chemical shift that was noted on the $\mathrm{C}-4$ was due to the resonance of the lactone carbon. The C-5 appeared at $\delta 121.9$ while C-6 appeared at $\delta 116.3$. The C-7 appeared at $\delta 114.9$ and the C-8 appeared at $\delta$ 146.1. The down field chemical shift of C-8 showed the resonance of one oxygen. C-5' appeared at $\delta 174.1$ which is associated with chemical shift of methyl ester and C-8' appeared at $\delta 207.8$, which is associated with ketone. ${ }^{1}{ }^{H}-{ }^{13} \mathrm{C}$ connectivity's were established through HSQC spectrum. The $\mathrm{H}-3$ ( $\delta$ 6.13) showed cross peak with $\mathrm{C}-3(\delta 114.3)$, while $\mathrm{H}-4(\delta 7.38)$ showed cross peak with 4-C $(\delta 145.6)$. The $\mathrm{H}-7$ ( $\delta 7.03)$ showed cross peak with C-7 signal at $\delta 114.9$, while $5-\mathrm{H}(\delta 6.96)$ and $\mathrm{H}-6(\delta 6.76)$ showed cross peak with C-5 and C- 6 signal at $\delta 121.9$ and $\delta 116.3$ respectively. The $\mathrm{HMBC}$ spectral data showed correlations between $\mathrm{H}-3$ ( $\delta$ 6.13) and the carbonyl at $\mathrm{C}-2$ ( $\delta$ 161.8). The doublet signal of $\mathrm{H}-4(\delta 7.38)$ showed correlation with $\mathrm{C}-2$ ( $\delta$ $161.8), \mathrm{C}-3(\delta 114.3)$ and $\mathrm{C}-8 \mathrm{a}(\delta 148.9)$. The doublet signal of $\mathrm{H}-7$ $(\delta 7.03)$ also showed correlation with C-4 ( $\delta 145.6), C-8(\delta 146.1)$, $C-5(\delta 121.9)$ and C-8a $(\delta 148.9)$. The doublet of a doublet signal of $\mathrm{H}-5(\delta 6.96)$ also showed correlation with $\mathrm{C}-6(\delta 116.3), \mathrm{C}-8(\delta$ $146.1)$, and $C-7(114.9)[18,19]$. Moreover, the doublet signal of $\mathrm{H}-6(\delta$ 6.76) showed correlation with C-8 $(\delta$ 146.1) and C-8a $(\delta$ 148.9). ${ }^{1} \mathrm{H}-{ }^{1} \mathrm{H}$ Cosy spectrum connectivity showed correlation of proton with signal at $\delta 6.13(\mathrm{H}-3)$ and that of $\delta 7.38(\mathrm{H}-4)$ and vice versa. Similarly, proton signal at $\delta 6.76(\mathrm{H}-6)$ showed correlation with proton at $\delta 6.96(\mathrm{H}-5)$. There was a Meta coupling between the proton with signal $\delta 6.96(\mathrm{H}-5)$ with a coupling constant $\mathrm{J}=2.06 \mathrm{~Hz}$ and $\delta 7.03(\mathrm{H}-7)$ with coupling constant $\mathrm{J}=2.06 \mathrm{~Hz}$. Comparing these data with that in literature led to the conclusion that the compound identified as $(E)$-methyl-4- hydroxyl -7- oxo-5(2-oxo-2H-Chromen -8-yloxy) oct-2- enoate 2 with structure shown in Figure 1. The percentage mortality, $\mathrm{LC}_{50}$ and $\mathrm{LC}_{90}$ values after 48 hours of exposure for the 8-hydroxy-2H -chromen -2-one 1 and (E)-methyl-4- hydroxyl -7- oxo-5- (2-oxo-2H-Chromen -8-yloxy) oct-2- enoate $\mathbf{2}$ as a mixture are summarized in Table $\mathbf{2}$. The result of the acaricidal tests demonstrated that the compound mixture was potent with mortality recorded $\mathrm{LC}_{50}$ and $\mathrm{LC}_{90}$ values of 2.96 and $6.09 \mathrm{mg} / \mathrm{ml}$ respectively. The activity compared favorably well with those of commercial amitraz which was used as the reference standard. Extensive phytochemical investigation of $A$. schimperi led to the isolation of two coumarin derivatives. The comparison of the $\mathrm{LC}$ values of a mixture of compound $\mathbf{1}$ and 2 showed activity against $R$. appendiculatus. The acaricidal mortality of the compounds had dose dependent effect that is; the activity was proportional to the concentration. A few reported studies of acaricidal activity of methanolic crude extracts have been reported from literature and no acaricidal activity of pure compounds from the extracts has ever been reported. The larvicidal action of $A$. schimperi could be related to the presence active principle ouabain $\left(\mathrm{C}_{30} \mathrm{H}_{46} \mathrm{O}_{12}\right)$ a very poisonous, amorphous cardiac glycoside which at toxic amounts decreases the electric conductivity through the heart causing irregular heart contractility and arrest [28]. The larvicidal activity of plant extracts of Aloe pirottae and $A$. schimperi leaves gave $100 \%$ mortality at $160 \mathrm{ppm}$ and $480 \mathrm{ppm}$ respectively against Anopheles arabiensis fourth instar [29]. Extracts of $A$. schimperi demonstrated larvididal activity by producing $\mathrm{LC}_{50} 4.50 \mathrm{mg} / \mathrm{ml}$ and $\mathrm{LC}_{99} 8.84 \mathrm{mg} / \mathrm{ml}$ on $R$. appendiculatus while $\mathrm{LC}_{50} 2.784 \mathrm{mg} / \mathrm{ml}$ and $\mathrm{LC}_{99} 8.945 \mathrm{mg} / \mathrm{ml}, B$. decoloratus respectively [14]. The compound mixture (1 and $\mathbf{2}$ ) showed relatively high acaricidal mortality of the tested $A$.

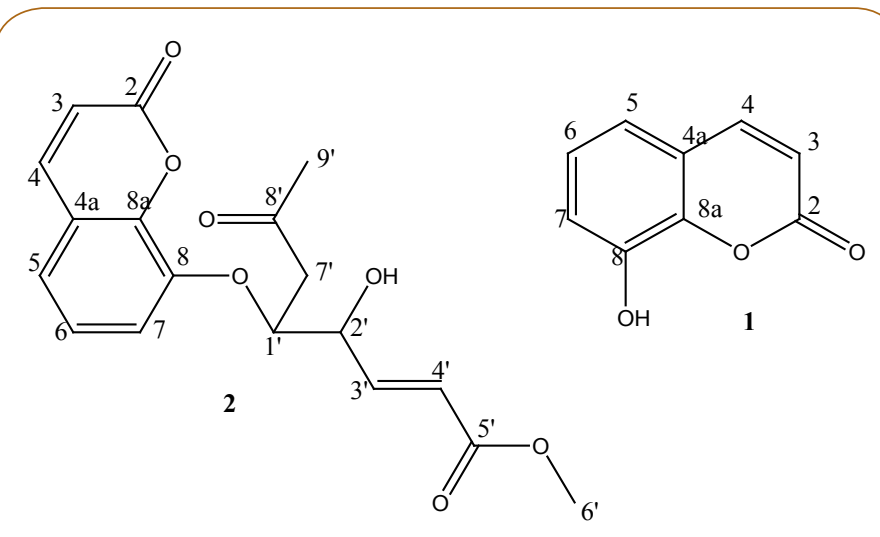

Figure 1 Structures of compounds 1 and 2. 
Table 2 Acaricidal assay result for compound mixture 1 and 2.

\begin{tabular}{|c|c|c|c|}
\hline \multirow{2}{*}{ Concentration (mg/ml) } & \multicolumn{3}{|c|}{$\%$ Larval mortality \pm SD } \\
\hline & After 12 hours & After 24 hours & After 48 hours \\
\hline 2.0 & $10.0 \pm 0.0$ & $14.0 \pm 5.8$ & $23.0 \pm 5.8$ \\
\hline 2.4 & $13.3 \pm 5.8$ & $23.3 \pm 5.8$ & $37.0 \pm 5.8$ \\
\hline 3.0 & $23.3 \pm 5.8$ & $40.0 \pm 10.0$ & $57.0 \pm 5.8$ \\
\hline 3.6 & $30.0 \pm 10.0$ & $50.0 \pm 10.0$ & $60.0 \pm 10$ \\
\hline 4.2 & $37.0 \pm 5.8$ & $57.0 \pm 5.8$ & $67.0 \pm 5.8$ \\
\hline 4.8 & $63.3 \pm 15.3$ & $73.3 \pm 5.8$ & $80.0 \pm 0.0$ \\
\hline 5.4 & $70.0 \pm 5.8$ & $83.3 \pm 5.8$ & $90.0 \pm 5.8$ \\
\hline Amitraz $(0.125 \mathrm{mg} / \mathrm{ml})^{\mathrm{m}}$ & $100.0 \pm 0.0$ & $100.0 \pm 0.0$ & $100.0 \pm 0.0$ \\
\hline$\left(\right.$ Distilledwater+DMSO) ${ }^{n}$ & $0.0 \pm 0.0$ & $0.0 \pm 0.0$ & $0.0 \pm 0.0$ \\
\hline $\mathrm{LC}_{50}$ & $4.39(3.70-6.12)$ & $3.53(2.93-4.29)$ & $2.96(2.22-3.55)$ \\
\hline $\mathrm{LC}_{90}$ & $8.67(6.19-26.45)$ & $6.85(5.25-14.63)$ & $6.09(4.70-13.32)$ \\
\hline
\end{tabular}

mPositive control; ${ }^{\mathrm{N}} \mathrm{Negative}$ control

schimperi and this can help a great deal in helping to combating tick related diseases. With pressure from an increasing human population and declining per-capita food production in Africa, there is an urgent need to develop appropriate technologies so as to optimize livestock production. Discovery of effective natural products among native plants will introduce new, high value crops for farming and open increased job opportunities for agricultural workers in the extraction processing industry. It will also offer an affordable alternative to the rather expensive acaricides which can be exploited locally by the local communities.

\section{Conclusion}

This study reports that Coumarin compounds 8-hydroxy-2H -chromen -2- one 1 and $(E)$-methyl-4- hydroxyl -7- oxo-5- (2-oxo$2 \mathrm{H}$-Chromen -8-yloxy) oct-2- enoate compounds may have potential application in the control of ticks. The study justifies that the bioactive constituents of the plant $A$. schimperi have the potential useful agents in the control of the vector, which is a host of infectious agents. Such findings avail an opportunity for developing newer and more selective biodegradable and naturally acaricidal compounds, of more potent against $R$. apendiculatusas an alternative to rather more expensive and non-environmentally friendly synthetic acaricides.

\section{Acknowledgements}

The authors wish to thank Egerton University for funding this research. We are also grateful to Prof. ST Kariuki, for the assistance in the identification and collection of the plant material. Special thanks go to Mr. Richard Ochieng for the assistance he offered on the rearing of $R$. appendiculatus. 


\section{References}

1 Jongejan F, Uilenberg G (2004) The global importance of ticks. Parasitology 129: 3-14.

2 George JE, Pound JM, Davey RB (2004) Chemical control of ticks on cattle and the resistance of these parasites to acaricides. Parasitology 129: 353-366.

3 Graft JF, Gogolewski R, Leach-bing N, Sabatini GA, Molento MB, et al. (2004) Tick control: An industry point of view. Parasitol 129: 427-442.

4 Nurhayat T, Mei W, Cristina A, Amar GC, Jon FP, et al. (2013) Bioactivity guided Investigation of Geranium Essential oils as natural Tick Repellents. J Agric Food Chem 6: 4101-4107.

5 Wanyama JB (2000) Ethno veterinary knowledge research and development in Kenya. In: International Conference on Medicinal Plants, Traditional Medicine and Local Communities in Africa: Challenges and Opportunities of the New Millennium, Kenya.

6 Seena V, Ranjana S (2012) Ethno medicinal plants and its effects on public Health. J Pharm Biomed Sci 21: 22-23.

7 Tageg H, Mohammed E, Asres K, Gebre-Mariam T (2005) Antimicrobial activities of some selected traditional Ethiopian medicinal plants used in the treatment of skin disorder. J Ethnopharmacol 100: 168-175.

8 European Food Safety Authority- EFSA (2009) Compendium of botanicals that have been reported to contain toxic additive, psychotropic or other substances of concern on request of EFSA. Journal of European Food Authority 7: 100.

9 Jonathan K, Bernard A, Margaret K, Timothy OB, Christopher H, et al. (2012) A poisonous surprise under the coat of the African crested rat. A proceeding of the Royal society 1729 : 675-680.

10 Walker JB, Keirans JE, Horak IG (2000) The Genus Rhipicephalus. Cambridge, Cambridge University Press.

11 Norval RAI, Sutherst RW, Kurki J, Gibson JD, Kerr JD (1988) The effect of the brown ear tick Rhipicephalus appendiculatus on the growth of Sanga and European breed cattle. Vet Parasitol 30: 149-164.

12 Sanin J, Reghu R, Sunil AR, Ajith KKG, Suresh NN, et al. (2012) Jatrophacurcas (Linn) Leaf extract - a possible alternative for population control of Rhipicephalus (Boophilus) annulatus. Asian pacific Journal of Tropical Disease 2: 225-229.

13 Barbara S, David MR, Alexander P, Sithes L, William TC, et al. (2008) A natural history of botanical therapeutics. Metabolism 1: S3-S9.

14 Mark ON, James MM, William OO, Cyrus GW, Adamson LL, et al. (2008) Comparative larvicidal efficacy of Acokantheraschimperi (Apocynaceae) and Psiadiapuntulata (Compositae) against
Boophilusdecolaratus and Rhipicephalus appendiculatus Acari: ixodidae. 11: 22

15 Tamboura HH, Sawadogo LL, Kaboré H, Yameogo SM (2000) Ethnoveterinary medicine and indigenous pharmacopoeia of Passoré Province in Burkina Faso. Ann NY Acad Sci 916: 259-264.

16 Balley KP (1960) Note on the rearing of Rhipicephalus appendiculatus and infection with Theilariaparva for experimental transmission. Bull Epizoot Dis Afr 8: 33-43.

17 Venkateswara GR, Sambasiva KR, Annamalia T, Mukhopadhayay T (2009) Newcoumarindiol from the plant chloroxylonswietenia DC. Indian J Chem 48B: 1041-1044.

18 Silva E, Maria V (2012) LC-NMR and other hyphenated NMR Techniques Over views and applications.

19 Metin B (2005) Basic ${ }^{1} \mathrm{H}_{-1}{ }^{13} \mathrm{C}$ NMR Spectroscopy.

20 Ashraf A, El B, Abdel-Hamid NM (2006) Antibacterial Coumarins isolated from

21 Seyed MR, Gholamhassan I, Mhdi D (2010) Coumarins from Zosimaabsinthifolia seeds, with allelopatic effects. EurAsian Journal of Biosciences 4: 17-22.

22 Lozhkin AV, Skanyan El (2006) Structure of chemical compounds methods of analysis and process control. Pharmaceutical chemistry Journal 40: 47-56.

23 Mohamed H, El-Razek A, Yang-Chang W, Fang-Rang C (2007) Sesquestapenecoumarins from Ferula foetida. Journal of Chinese chemical society 54: 235-238.

24 Dao TT, Tran TL, Kim J, Nguyen PH, Lee EH, et al. (2012) Terpenylated coumarins as SIRT1 activators isolated from Ailanthus altissima. J Nat Prod 75: 1332-1338.

25 Renmin L, Lei F, Ailing S, Lingyi K (2004) Preparative isolation and purification of coumarins from Cnidiummonnieri (L) cussion by high speed counter - current chromatography. J chromatogr A1055: 7176.

26 Zaffer MA, Mohammed A, Showkat RM (2012) New sester and triterpenic Coumarin ethers from the roots of Aeglemarmelos (L.) Corr. Journal of Natural plant Resources 2: 636-643.

27 Erno P, Philippe B, Martin B (2008) Structure Determination of organic compounds table of structure spectral data.

28 Melero P, Medarde M, San FA (2000) A Short Review on Cardiatonic steroids and their Aminoguanidine Analogues. Moecules 5: 51-81.

29 Damtew B, Beyene P, Habte T, Zessmede A (2014) Larvicidal and Adulticidal effects of extracts from some Indigenous plants against the malaria vector, Anopheles arabiensis (Diptera: Culicidae) in Ethiopia. J Biofertil Biopestic 5: 1-9. 